TI 2011-081/3

Tinbergen Institute Discussion Paper

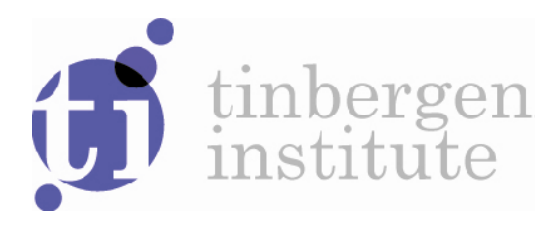

\title{
The Regional Impact of Monetary Policy in Indonesia
}

Masagus M. Ridhwan ${ }^{a, b}$

Henri L.F. de Groota,c

Piet Rietvelda

Peter Nijkampa

a Dept. of Spatial Economics, Faculty of Economics and Business, University of Amsterdam, and Tinbergen Institute;

b Bank Indonesia, Jakarta, Indonesia;

c Ecorys NEI, Rotterdam. 
Tinbergen Institute is the graduate school and research institute in economics of Erasmus University Rotterdam, the University of Amsterdam and VU University Amsterdam.

More TI discussion papers can be downloaded at http://www.tinbergen.nl

Tinbergen Institute has two locations:

Tinbergen Institute Amsterdam

Gustav Mahlerplein 117

1082 MS Amsterdam

The Netherlands

Tel.: +31(0)205251600

Tinbergen Institute Rotterdam

Burg. Oudlaan 50

3062 PA Rotterdam

The Netherlands

Tel.: +31(0)10 4088900

Fax: +31(0)104089031

Duisenberg school of finance is a collaboration of the Dutch financial sector and universities, with the ambition to support innovative research and offer top quality academic education in core areas of finance.

DSF research papers can be downloaded at: http://www.dsf.nl/

Duisenberg school of finance

Gustav Mahlerplein 117

1082 MS Amsterdam

The Netherlands

Tel.: +31(0)20 5258579 


\title{
The Regional Impact of Monetary Policy in Indonesia
}

\author{
Masagus M. Ridhwan ${ }^{\mathrm{a}, \mathrm{b}, \mathrm{c}}$, Henri L.F. de Groot ${ }^{\mathrm{a}, \mathrm{b}, \mathrm{d}}$, Piet Rietveld ${ }^{\mathrm{a}, \mathrm{b}}$, Peter Nijkamp ${ }^{\mathrm{a}, \mathrm{b}, 1}$ \\ ${ }^{a}$ VU University Amsterdam, Department of Spatial Economics, The Netherlands \\ ${ }^{b}$ Tinbergen Institute, Amsterdam-Rotterdam, The Netherlands \\ ${ }^{\mathrm{c}}$ Bank Indonesia, Jakarta, Indonesia \\ ${ }^{\mathrm{d}}$ Ecorys NEI, Rotterdam
}

\begin{abstract}
.
This paper employs Vector Autoregression (VAR) models to measure the impact of monetary policy shocks on regional output in Indonesia. Having incorporated a possible structural break following the aftermath of the 1997-98 Asian Crisis, the impulse response functions derived from the estimated models reveal substantial cross-region variations in policy responses in terms of their magnitude and timing. Our work complements the existing literature by providing insights from a developing country. The results support previous findings that the differential regional effects of monetary policy are significantly related to sectoral composition (especially the share of manufacturing), providing evidence for the relevance of the interest rate channel of monetary policy. We also find that firm-size contributes to the differences, providing evidence for the relevance of the credit channel.
\end{abstract}

Keywords: monetary policy transmission, regional development, vector autoregression JEL codes : E44, E52, R11, C32

\footnotetext{
${ }^{1}$ Helpful comments by Jakob de Haan and Eelke de Jong are gratefully acknowledged. The usual disclaimer applies. Corresponding author: Henri L.F. de Groot, Department of Spatial Economics, VU University Amsterdam, De Boelelaan 1105, 1081 HV Amsterdam, The Netherlands. Email: h.l.f.de.groot@vu.nl.
} 


\section{Introduction}

The discussion of how monetary policy affects real economic activity remains open and challenging, both theoretically and empirically. Monetary policy is structurally designed for a national objective, say price stability. The effects of monetary policy actions can, however, vary across regions within an economic entity, depending on the regional industrial composition, the financial structure, trade relationships, and the institutional environment. As a consequence, the real economic impacts of monetary policy actions need not be homogeneous across regions. ${ }^{2}$ This holds especially for a developing country like Indonesia with its vast geography and diverse social and economic conditions. For example, monetary policy tightening may provide a conducive macroeconomic environment for Java's economy, while the poorer outer islands may suffer from higher interest rates and a tighter money supply (for further discussion, see Ridhwan, 2011). Accordingly, the impulses and propagation mechanisms of uniform policies may have distributional implications for the participating regions. $^{3}$

Therefore, in order to counteract regional divergences, a country or a monetary union relies on a redistribution (fiscal) policy, as it allows for an interregional risk-sharing mechanism (see, for example, Von Hagen, 1999); Athanasoulis and Van Wincoop, 2001). However, the scope and capacity of fiscal policy in Indonesia is generally limited, especially after the 1997-98 crisis struck the national economy. Anti-deficit policies initiated by the Government of Indonesia in the post-crisis period have reduced the possibility of using fiscal policy as a stabilizing tool in the light of regional imbalances. ${ }^{4}$ In addition, since the era of regional autonomy, resource rich regions have been granted a large increase in revenue sharing from the central government. As a result, this constrains the central government's

\footnotetext{
${ }^{2}$ The standard literature on the optimum currency area (OCA) theory further argues that, if some regions or participating economies within a currency union face a common shock, then adjustment mechanisms could take place through flexible factor markets (high factor mobility and adjusting factor prices), and hence will help to counteract economic divergence (see De Grauwe, 2000; Baldwin and Wyplosz, 2004). In contrast, Krugman (1991) argues that economic and monetary integration may facilitate industries to become more clustered in order to exploit 'increasing returns to scale' and other locational advantages. As a result, the risk of asymmetric effects among participating economies due to common shocks tends to be inevitable.

${ }^{3}$ Hanson et al. (2006) found that a 25 basis point increase in the Fed Funds rate widens the dispersion in income growth in US States by 22 basis points.

${ }^{4}$ Under an agreement with IMF (International Monetary Fund), Indonesia was bailed out for the 1997-98 crisis. The main condition imposed was that the national government budget deficit should be less than 3 per cent of GDP. To achieve this target in the decentralization era, the national government has imposed a strict fiscal policy on local authorities, nor are they allowed to incur budget deficits. Furthermore, foreign borrowings by local authorities are strictly prohibited (see http://www.djpk.depkeu.go.id/).
} 
options to use re-distributional policies. Furthermore, because Indonesia de jure is also a monetary union (a collection of participating regions within a country), the issue of whether it is an optimal currency area (OCA) or not may not so be relevant, but an issue remains how to find the optimal response to deal with the asymmetric shocks and formulate optimal stabilization policies. Evaluating the real effects of monetary policy for Indonesia could be even more relevant if we also consider the impact of the macroeconomic shocks that adversely hit its economy, i.e. the notorious 1997-98 crisis. As shown in Figure 1, the crisis has not only reduced its Gross Domestic Product (GDP) dramatically (by about 13 per cent), but also caused inter-provincial growth rates to vary widely.

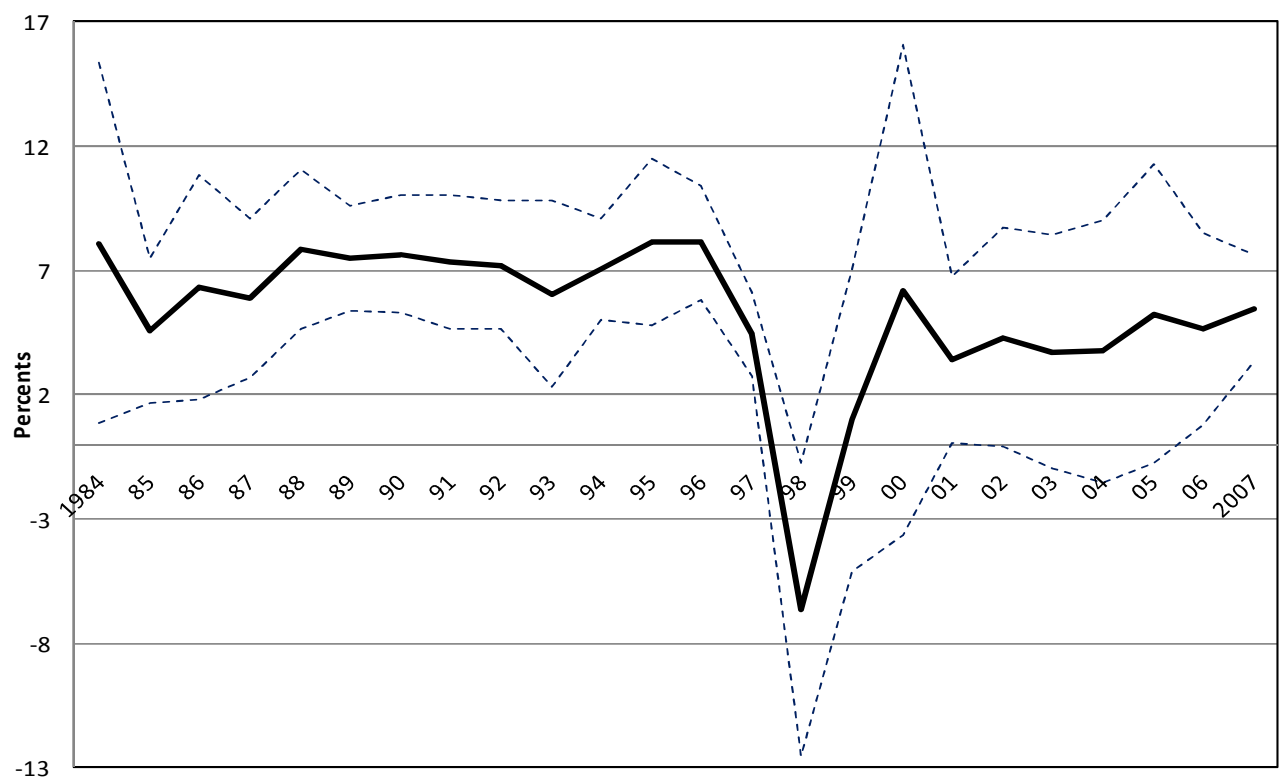

Figure 1. Cross-sectional mean GRP growth rate per period (with 1 standard deviation bands)

In the literature, several studies have recently investigated the regional effects of monetary policy across the US States using Vector Autoregression (VAR) models (see Carlino and DeFina, 1998, 1999; Owyang and Wall, 2009). ${ }^{5}$ Previous studies relied upon structural form equations (see Fishkind, 1977; Miller, 1978; Garrison and Chang, 1978). However, a major shortcoming of the older studies that they ignore the importance of feedback effects among the

\footnotetext{
${ }^{5}$ Relevant studies in Europe have been conducted by, for instance, Arnold and Vrugt (2004) for the German regions; Rodriguez-Fuentes (2005) for the Spanish regions; and Dow and Montagnoli (2007) for the Scottish and UK economies.
} 
variables. Those studies may also suffer from an identification problem due to reverse causality issues (e.g. Sims, 1980; Faust, 1988).

In this paper we empirically examine how economic activity in each of the 26 provinces responds to monetary policy changes using Vector Autoregression (VAR) models estimated over the period 1990:1 to 2007:4. Our work complements the literature by providing insights from developing countries. To the best of our knowledge, this study is the first for the Indonesian case. ${ }^{6}$ Having derived impulse response functions of the policy shocks, we subsequently evaluate whether the effects are different across regions. We conclude investigating what factors may explain the differential effects of monetary policy actions across regions.

The paper is organized as follows. Section 2 provides a brief review of regional monetary transmission mechanisms. Section 3 summarizes the VAR methodology, model specification, and the data. Section 4 presents and analyses the empirical results; and, finally, Section 5 concludes.

\section{Transmission of Monetary Policy at the Sub-National Level}

Sources of economic fluctuations that affect an economic region can be either nation-wide or regional specific (idiosyncratic shocks). The first type of shock may refer to a common policy that is imposed to all regions, such as a change in monetary policy rate. An example of the latter type of shock is a weather-related shock. Focusing on the first type of policy shocks, empirical studies suggest that the national monetary policy may generate differential effects across regions through different transmission channels. The first channel is the interest rate channel. The degree of sensitivity to interest rate shocks differs across industries. Manufacturing and construction are, for example, highly interest rate sensitive (for a recent survey, see Ridhwan et al., 2010). If this is the case, regions with a high proportion of interestelastic industries may therefore be especially vulnerable to a tightening of monetary policy. In other words, monetary contractions may reduce the demand for investment goods and (durable) consumer goods by increasing the real costs of capital to firms and consumers (see Taylor, 1995; Mishkin, 1996).

\footnotetext{
${ }^{6}$ A related study has been conducted by Bank Indonesia (Warjiyo and Agung, 2002), but it used aggregate (national) data.
} 
Another regional channel of monetary transmission refers to the credit channel (Bernanke and Gertler, 1995). Regional sensitivity to monetary policy depends on a concentration of firms with a certain size (broad credit channel) and the concentration of banks with a certain size (narrow credit channel). The first channel occurs since larger firms have better access to external sources of finance, while small firms are largely dependent on conventional financial institutions, notably bank loans (Gertler and Gilchrist, 1993; Oliner and Rudebusch, 1996). Therefore, if a region has a high concentration of small firms, this region will also experience a relatively large negative impact on output as a result of a monetary contraction. The narrow credit channel arises due to regional variation in bank size (Kashyap and Stein, 2000). Given that larger banks have more alternative financial sources while small (rural) banks mostly resort to local financial markets, cross-regional differences in the banksize composition may lead to differential effects in response to national monetary contractionary policy.

The exchange rate channel may also be relevant for an open economy such as Indonesia. The higher relative interest rate (monetary tightening) induces a capital inflow, which causes the exchange rate to appreciate. Since the appreciation leads to price increase in export products, thereby an economy may face a loss of competitiveness due to a decline in the demand for exports and an increase in consumer spending, induced by the positive income effect. In the meantime, it also causes a fall in the (domestic) price level. Directly since it reduces the cost of imported goods and the size of the mark-up; and indirectly since it worsens the competitive position of domestic firms (and hence net exports). Consequently, this mechanism suggests that regions with more export-intensive industries may be more responsive to monetary policy innovations (see, for example, Hayo and Uhlenbrock, 2000).

Conversely, Ber et al. (2001) find that export-intensive firms are cushioned from monetary policy shocks. When domestic interest rates are tightened, exporting firms are able to raise credit on foreign currency markets (where they have contracts and have built a reputation with local lenders) and so do not have to reduce investment. Their findings provide an alternative explanation for the exchange rate channel through which regions with a high degree of trade openness (export-intensive) are even less prone to monetary policy shocks. As asserted by Darby and Phillips (2007), this may be one reason of why a number of the existing 
studies do not explicitly try to model the exchange rate effect given that the empirical evidence in this area has so far been inconclusive. ${ }^{7}$

\section{Overview of the Indonesian economy}

Indonesia is known as the world's largest archipelago country with more than 13,000 islands. However, more than 90 per cent of its population resides in its five biggest islands: Java, Sumatra, Kalimantan, Sulawesi, and Papua. As a 'unique' country that is composed of so many islands, there is indeed a large spatial diversity amongst its provinces. Some notable variations are due to the distinctive structure and characteristics of its regions, with respect to, socioeconomic conditions, natural resource endowments, institutions, geography, and ethnicity, among others. In 2005, per capita regional product in the richest province, East Kalimantan, was around 13 times higher than in the poorest, Maluku (see Table 1). The poverty incidence ranged from 3.4 per cent of the population in Jakarta to 42 per cent in Papua (for further details, see, Hill et al., 2008; Ridhwan, 2011).

On the basis of its economic structure, the Indonesian economy can be described as a dual economy. The Java zone (Java-Bali provinces) is characterized by a large concentration of manufacturing activities (about three-quarters of non-oil and gas national manufacturing firms located here), more mobile factors, a labour pool with a higher education level, better institutions, and relatively good infrastructure. The economic structure in Off-Java (the rest of the zones) is highly dependent on the primary sector, notably agriculture and mining. This situation may represent what Krugman (1991) terms a "core" (Java) "periphery" (off-Java) structure, driven by agglomeration economies.

Indonesia constitutes a single monetary area with a common currency. In the aftermath of the crisis, Indonesia underwent some major macroeconomic reforms. On the fiscal side, since 2001 fiscal decentralization has formally replaced the old centralized system. On the monetary side, Indonesia abandoned a quasi-fixed exchange rate regime in favor of a freelyfloating exchange rate regime in mid-1997. The banking sector has also undergone some substantial restructuring and re-capitalization, in which the number of banks has been reduced from 237 in 1997 to 161 in 2000 . From a spatial point of view, more than 80 per cent of the

\footnotetext{
${ }^{7}$ Another channel that is commonly discussed in regional monetary transmission is the spillover effect due to spatial interdependencies. Given the limited data on Indonesia's regional economies, this channel will not be examined, and will be left for future research.
} 
branches of the national bank are located in Java, and they are mostly located in DKI Jakarta, the national financial centre (for further details, see Ridhwan, 2011), further underlining the dominant role of Java in the national economy.

Table 1. Selected Indonesian provincial indicators

\begin{tabular}{lrrrrr}
\hline Province & $\begin{array}{r}\text { Land area } \\
\left(\mathrm{km}^{2}\right)\end{array}$ & $\begin{array}{r}\text { Population } \\
\text { in 2005 (in } \\
\text { thousands) }\end{array}$ & $\begin{array}{r}\text { GRP per capita } \\
\text { in 2005 } \\
(\mathrm{NAD}=100)\end{array}$ & $\begin{array}{r}\text { Share in } \\
\text { GDP }(\%)\end{array}$ & $\begin{array}{r}\text { Trade share } \\
\text { in 2005 (\% } \\
\text { of GDP) }\end{array}$ \\
\hline Aceh (NAD) & 56,501 & 4,032 & 100.00 & 2.08 & 60.41 \\
North Sumatra (NS) & 72,428 & 12,451 & 81.45 & 5.24 & 81.15 \\
West Sumatra (WS) & 42,225 & 4,566 & 73.68 & 1.74 & 31.19 \\
Riau (Ri) & 87,844 & 5,854 & 216.14 & 6.54 & 102.75 \\
Jambi (Jm) & 45,348 & 2,636 & 55.24 & 0.75 & 106.94 \\
South Sumatra (SS) & 76,727 & 7,826 & 85.31 & 3.45 & 71.49 \\
Bengkulu (Bk) & 19,795 & 1,549 & 46.47 & 0.37 & 45.77 \\
Lampung(Lm) & 45,819 & 7,116 & 47.55 & 1.75 & 75.99 \\
DKI Jakarta (DKI) & 740 & 8,860 & 384.50 & 17.60 & 122.25 \\
West Java (WJ) & 45,944 & 47,994 & 73.06 & 18.12 & 107.19 \\
Central Java (CJ) & 32,800 & 31,978 & 51.61 & 8.53 & 105.18 \\
DI Yogyakarta (DIY) & 3,133 & 3,344 & 58.45 & 1.01 & 84.53 \\
East Java (EJ) & 46,690 & 36,294 & 81.50 & 15.29 & 95.90 \\
Bali (Ba) & 5,449 & 9,029 & 71.86 & 1.26 & 138.94 \\
West Kalimantan (WK) & 120,114 & 4,052 & 66.77 & 1.40 & 63.19 \\
Central Kalimantan (CK) & 153,565 & 1,915 & 84.11 & 0.83 & 61.06 \\
South Kalimantan (SK) & 38,884 & 3,282 & 75.78 & 1.29 & 78.39 \\
East Kalimantan (EK) & 194,849 & 2,849 & 379.04 & 5.58 & 88.52 \\
North Sulawesi (NSu) & 26,096 & 3,051 & 55.86 & 0.88 & 177.82 \\
Central Sulawesi (CSu) & 68,090 & 2,295 & 58.97 & 0.70 & 24.98 \\
South Sulawesi (SSu) & 62,904 & 7,510 & 53.81 & 2.36 & 75.09 \\
Southeast Sulawesi (SeSu) & 36,757 & 1,963 & 47.18 & 0.48 & 67.52 \\
West Nusa Tenggara (WN) & 19,709 & 4,184 & 41.98 & 0.91 & 55.28 \\
East Nusa Tenggara (EN) & 46,138 & 4,260 & 26.38 & 0.58 & 102.19 \\
Maluku (Ma) & 87,310 & 2,136 & 29.69 & 0.33 & 41.89 \\
Papua (Pa) & 424,501 & 2,518 & 126.17 & 1.64 & 154.39 \\
& & & & & \\
\hline Source: Oran & & & & &
\end{tabular}

Source: Own calculation based on BPS data (various years).

\section{Empirical Analysis}

\subsection{A regional monetary VAR model}

In order to identify the responses of regional economies to monetary policy innovations, we employ a time-series econometrics methodology called Vector Autoregression (VAR). The method is capable of isolating the different possibilities of shocks (the orthogonalization 
process $)^{8}$ between all system variables over a period of time, and thereby allows us to identify the sources and effects of economic disturbances.

We begin by modeling the economic activity in the 26 provinces of the Indonesian economy using VAR. Let $Y_{t}$ be the vector of endogenous variables for province $i$ in period $t$ :

$$
Y_{t}=\left(y n_{t}, p n_{t}, r_{t}, e_{t}, y i_{t}\right)^{\prime},
$$

where $y n_{t}$ is a measure of aggregate Indonesian output; $p_{t}$ is the aggregate price measure; $r_{t}$ is an interest rate variable that represents monetary policy actions; $e_{t}$ is the exchange rate; and $y i_{t}$ is real output in province $i$. We also define a vector of exogenous variables $\left(X_{t}\right)$ which consists of the oil and commodity price index $\left(p c_{t}\right)$, and the foreign interest rate $\left(f r_{t}\right)$ (further elaborations, see Section 4.3).

We can then write a structural-form equation of our VAR specification:

$$
R(L) Y_{t}=C(L) X_{t}+\varepsilon_{t},
$$

where $R(L)$ is an $n \times n$ polynomial matrix in the lag operator; $C(L)$ is an $n \times k$ polynomial matrix in the lag operator; $Y_{t}$ is an $n \times 1$ vector of endogenous variables; and $X_{t}$ is a $k \times 1$ vector of exogenous variables (see the above specification). $\mathcal{E}_{t}$ is an $n \times 1$ vector of structural disturbances, with a zero mean white-noise process and with a positive definite covariance matrix, i.e. $\operatorname{var}\left(\varepsilon_{t}\right)=\Lambda$, where $\Lambda$ is a diagonal matrix.

The reduced-form that corresponds to this structural model is:

$$
Y_{t}=A(L) Y_{t}+B(L) X_{t}+\mu_{t}
$$

\footnotetext{
${ }^{8}$ The VAR methodology is, for example, able to isolate the effect of monetary policy from the effect of all other forms of policy (fiscal, industrial, regional, etc.) which are being implemented simultaneously. More technical details of the VAR methodology can be found in standard econometric textbooks such as Hamilton (1994), Lütkepohl (2007), Favero (2001) and Enders (2004).
} 
where $A(L)$ and $B(L)$ are polynomial matrices, and $\mu_{t}$ is a vector of reduced-form disturbances, with $\operatorname{var}\left(\mu_{t}\right)=\Sigma$. Next, let $P$ be the contemporaneous coefficient matrix in the structural form; and let $Q(L)$ be the coefficient matrix in $R(L)$ without contemporaneous coefficients (lagged correlations). That is:

$$
R(L)=P+Q(L)
$$

The structural and reduced-form equations are then related as follows:

$$
A(L)=-P^{-1} Q(L) \text { and } B(L)=P^{-1} C(L)
$$

Equation (5) links each reduced-form coefficient matrix with its structural-form counterpart. This can be done if we know the $P$ matrix of contemporaneous correlations. $P$ is identified through the unrestricted covariance matrix of the reduced form $(\Sigma)$ and the diagonal covariance matrix of the structural form $(\Lambda)$ :

$$
\Sigma=P^{-1} \Lambda P^{-1^{\prime}}
$$

which is derived from the error-term correlations: $\mu_{t}=P^{-1} \varepsilon_{t}$ or $\varepsilon_{t}=P \mu_{t}$. Since $P$ is not uniquely identified due to the fact that there are many matrices that satisfy equation (6), $n^{2}$ identifying restrictions have to be imposed in order to link the reduced form initially estimated as $\mathrm{a} \operatorname{VAR}(n)$ to the structural form. Next, $n(n+1) / 2$ restrictions are imposed by making the covariance matrix of the residuals $(\Lambda)$ an identity matrix, and hence this leaves $n(n-1) / 2$ additional restrictions to be imposed in the system. This step is intended to achieve a meaningful interpretation of our impulse response functions.

Traditionally, VAR studies do not report parameters or standard test statistics. Instead, the approach of Sims (1980) is mostly used to summarize the estimated VAR systems by impulse-response functions (IRF). IRF trace out the effect of an unanticipated shock or an innovation in an endogenous variable, while all other shocks are kept to zero. As mentioned 
previously, the structural shocks are identified by imposing the components of the vector $\varepsilon_{t}$ to be orthogonal to each other.

\subsection{Identification restrictions and estimation issues}

As previously mentioned, since our main aim is to identify feedbacks of the regional economy following monetary policy shocks that can be summarized by an impulse response function, initially the system of equations in the VAR model should be imposed by using a set of identifying restrictions. Here we follow the tradition of recursiveness assumptions that rely upon a Choleski decomposition. In principle, the restriction imposes a recursive structure of the VAR by using causal ordering of the entire vector of endogenous variables. As pointed out by Christiano et al. (1998), the ordering of the variables in the interest rate equation is the only important identification criterion, given our primary interest in monetary policy transmission. ${ }^{9}$ The ordering of our endogenous variables is fairly standard in empirical monetary studies: real national output, aggregate price, monetary policy measure (interest rate), exchange rate, and real output in province $i .^{10}$ This ordering reflects our priors regarding the operation of monetary policy transmission mechanisms. Specifically, it assumes that the monetary policy rate is able to respond instantaneously to shocks in the other macroeconomic variables but can only affect them with a lag. ${ }^{11}$ Meanwhile, regional output can not affect the national macroeconomic variables, both upon impact and afterwards (where it is to be noted that our prime interest is to estimate the impact of the monetary policy shocks on regional output growth). ${ }^{12}$

\footnotetext{
${ }^{9}$ In general, innovations to monetary policy that can affect economic activity can be modeled as vector innovations to a system of equations (e.g. a VAR) in which monetary policy has been identified by structural restrictions on either the contemporaneous impacts of the variables (e.g. Christiano et al. 1998; Dedola and Lippi, 2005) or the long-run effects on the system of variables (e.g. Blanchard and Quah, 1989; and Shapiro and Watson, 1988). Here we focus on the first type of restriction.

${ }^{10}$ Several relevant studies have also used a resemblance identification scheme that is applied on state (regional) data, e.g. Beckworth (2010), Arnold and Vrugt (2004), and Kouparitsas (1999).

${ }^{11}$ For further discussion, see, e.g. Christiano et al. (1998).

${ }^{12}$ Although ideally we would also like to use regional prices in our model specification, however, lack of data for the Indonesia's regional price prevent us to take this route. To deal with the 'price puzzle' i.e. price increases after a contractionary monetary policy that may also be drawn a concern, as argued by Sims (1992) and Mihov (2001), the puzzle tends to be disappear as the model also includes commodity prices and exchange rates in its specification (see also, Leeper et al., 1996). As shown in equation (1), the two latter variables have also been incorporated, which may help in addressing problem of the prize puzzle that potentially arises in our regression.
} 
As shown in the vector of exogenous variables, foreign interest rates and international commodity (including oil) price measures are also included in the model to control for changes in the overall global economic stance of Indonesia's economy and the fluctuations of its commodity prices. Given that the Indonesian economy is unlikely to have an impact on the global economy, these variables are treated as exogenous. ${ }^{13}$

At this juncture, it is worth noting that the same shock is used across all provinces to facilitate a cross-region comparison. The models will be estimated without imposing further structural restrictions. Hence, we also allow this shock to die out of its own accord, rather than constrain it to a specific amount of time.

As a standard procedure in VAR, it is first required to verify the stationarity of all the variables used. To formalize this, we proceed by undertaking standard unit root tests such as the Augmented Dickey-Fuller (ADF) test and the Phillips-Perron (PP) test. Given some breaks that may occur in the series, we employ another type of test that formally deals with the possible structural break problem: namely, the Lanne, Lütkepohl and Saikkonen test (see Lanne et al., 2002). ${ }^{14}$

As most series in our sample appear to be integrated of order 1 according to different types of unit root tests, following the literature we should proceed to undertake a cointegration test. ${ }^{15}$ When the occurrence of the breaks is taken into account, the co-integration tests of Johansen-Mosconi-Nielsen (JMN) (2000) and Saikkonen-Lütkepohl (SL) (2000) are employed. Both these tests result in an indication of the presence of many co-integrating relations in our data-series: quite often we find three or more relations if the co-integrating rank is tested using all the variables listed above. This information suggests the appropriateness of the strategy suggested by Sims (1980) to estimate a VAR in levels, given the co-integration evidence. Considering our limited sample size and some evidence of break effects, it is likely to be insufficient to describe long-run relationships in the data. It is questionable whether true co-integration exists, as that basically relies on the low power of the

\footnotetext{
${ }^{13}$ Additionally, the exogeneity implies that the contemporaneous impact of the exogenous on the endogenous variables is allowed, but not the feedback (see Peersman and Smets, 2005).

${ }^{14}$ The unit root test results can be found in Appendix A. To identify the break date, we initially use the unit root test with unknown date, and later the date is determined endogenously. As discussed in Section 4.1, there are at least two relevant breaks that occurred during this study period: namely, the 1997-98 Crisis, and the 'Big Bang' fiscal decentralization policy that has been formally implemented in 2001.

${ }^{15}$ Further details are available upon request.
} 
tests. Thereafter, we estimate our models in natural log levels, except for interest rates, which are in percentages.

A similar approach can also be found in other studies, such as Sims et al. (1990), Christiano et al. (1996, 1998), Ramaswamy and Sløk (1998), Clements et al. (2001), and Weber et al. (2009). ${ }^{16}$ Additionally, Clements et al. (2001) give some other reasons for estimating the model in (log) levels. First, the first-differenced model could discard the information contained in the levels and lead to model specification, and, second, imposing inappropriate co-integrating relationships may bias impulse responses from the reduced-form VAR. $^{17}$

Since Indonesia's economy experienced an economic crisis between 1997 and 1999, it is important to allow for a possible break in our data. It is possible, in practice, to choose the shift date exogenously or endogenously, based on the characteristics of the data. Having examined the data more thoroughly, a structural shift eventually starts at the beginning of the year $2000 .{ }^{18}$ In the following, we assign a shift dummy for the post-crisis with a value of 1 , and 0 for the pre-crisis period. ${ }^{19}$ Additionally, since the crisis period between 1997:4 and 1999:4 is considered as a temporary shock, it can be represented by impulse dummies.

Following Weber et al. (2009), we can explicitly incorporate the structural shift in our structural VAR model by extending the VAR with a dummy variable $\left(d_{t}\right)$ that interacts with

\footnotetext{
${ }^{16}$ In addition, Owyang and Wall (2009) employ the level of the federal funds rate, since they consider a one-time monetary policy shock, and, furthermore, it allows them to analyze the dynamics of recovery from a monetarypolicy-induced recession. In contrast, Carlino and DeFina $(1998,1999)$ use the first difference of the federal funds rate as the monetary policy shock. In their set-up, because the shock to the federal funds rate recurs in each period, the monetary-policy-induced recession is permanent.

${ }^{17}$ Sims (1980) previously recommended against differencing, even if the variables contain a unit root. He argues that the goal of VAR is to uncover relationships between variables, not to produce meaningful parameter estimates.

${ }^{18}$ The stability in the political and economic sector in the aftermath of the crisis can be observed since the beginning of the year 2000, so macroeconomic indicators do not show any break effects compared with previous years. That may be a justification for why most studies conducted in Indonesia choose that the year as a 'recovery period', in which a new economic regime starts a new equilibrium path (for instance, Hardiyanto, 2007). In short, this period was marked by several major events: first, the adoption of a free-floating exchange rate regime in mid-1997; and second, the 2001 fiscal decentralization policy and some institutional changes in the new democratic country (see Hill, 2000). Finally, we also conducted some tests to allow the search for break-points exogenously (JMN test and SL test), and the results in general provide support for our selected break-points.

${ }^{19}$ In theory, an impulse dummy is introduced to account for special circumstances (events) such as the crisis. It is assumed that the (negative) effect would disappear, and things would return to normal in the following period(s).
} 
all lags of the system for both endogenous and exogenous variables. ${ }^{20}$ Thus, the previous baseline model can be reformulated as:

$$
Y_{t}=A(L) Y_{t-1}+B X_{t}+C(L) d_{t} Y_{t-1}+D d_{t} X_{t}+E Z_{t}+\mu_{t}
$$

Equation (7) contains the coefficients of the lagged endogenous variables that are equal to $A(L)$ for the period $1990: 1$ to $1999: 4$ and $A(L)+C(L)$ for $2000: 1$ to $2007: 4$. A similar treatment is also applied to the exogenous variables for both the coefficients $B$ and $B+D \cdot{ }^{21} Z$ contains all the deterministic variables which may consist of a constant and impulse dummies, while $E$ represents the model's parameters. Additionally, all variables are seasonally adjusted.

Furthermore, standard information criteria are used to select the lag lengths, notably the Hannan-Quinn (HQ) and Schwarz Criteria (SC). Given that there are inherently regional heterogeneities, the lag-length turns out to range between 2 and 3. Also, lag-length selection in each VAR was chosen to ensure no autocorrelation in the residuals (using the Lagrange multiplier test).

\subsection{Data}

The first two macroeconomic variables are aggregate output based on data of real GDP (gross domestic product) the Consumer Price Index (CPI) at the national level. The data for these variables are obtained from Statistics Indonesia (Badan Pusat Statistik, or BPS). In order to identify monetary policy innovations, we employ the 30-day Bank Indonesia's Treasury Bills (Sertifikat Bank Indonesia, or SBI). Alternatively, we use the money market interest rate i.e. the 30-day interbank money market. As argued by Agung (1998), the latter interest rate could be used as a monetary policy variable since Bank Indonesia often indirectly targets the interbank interest rates. Meanwhile, the exchange rate represents the value of a foreign nation's currency in terms of the home nation's currency. We use the rate of the US dollar against the rupiah (USD/Rp) as a measure for the nominal effective exchange rate. Both of these data are obtained from Bank Indonesia (the central bank of Indonesia).

\footnotetext{
${ }^{20}$ Ideally, to verify how structural changes (crisis) affect our data, we should split the data into different regime periods. However, because our data cover only a short period, such an approach is not feasible.

${ }^{21}$ Since these variables are treated as exogenous, we allow for a contemporaneous impact of the exogenous on the endogenous variables, but not for feedback (see also Peersman and Smets, 2005).
} 
For regional output, we use real (gross real domestic product) GRP based on 2000 constant prices. The data cover 26 provinces with a quarterly frequency from 1990:1 to 2007:4. ${ }^{22}$ After the "Big Bang" decentralization policy in 2001, some provinces were split, thus forming new separate provinces. Therefore, there are now 33 provinces. $^{23}$ In order to avoid imbalances in our data resulting from the splitting of provinces, we use GRP data for the pre-decentralization era as our reference point. We then integrate the post-decentralization data in order to have the same data set over time that refers to 26 provinces. The data source is Statistics Indonesia (Badan Pusat Statistik, or BPS).

As mentioned before, to account for external sources of disturbances to Indonesia's regional economies, our model also employs the international commodity price measure and foreign interest rates as exogenous variables. For the first variable, our proxy is the world oil and non-oil commodity price (also called the fuel and non-fuel commodity price) index. These data originate from the database of International Financial Statistics, IMF (International Monetary Fund). As a proxy for the latter variable, we employ the 3-month Singapore Interbank Offered Rate (SIBOR). This rate is commonly used as a reference rate of foreign debt transactions for the Indonesian economy. Additionally, Singapore is also known as a financial hub in the regions of Southeast Asia. These data are obtained from the CEIC database (visit, http://www.ceicdata.com/).

\section{Results and Discussion}

\subsection{Impulse responses to interest rate shocks}

As elaborated in Section 4, the focus of this study is to examine the impact of monetary policy on regional growth. Figures $2 \mathrm{a}-2 \mathrm{z}$ show the cumulative impulse responses of real output changes across the provinces resulting from a $1 \%$-point increase in the monetary policy rate (a

\footnotetext{
${ }^{22}$ Since 1999, BPS and BI have conducted a quarterly regional macroeconomic indicators survey. One of its products is the GRP data. We use these data here, while the data (quarterly GRP) for the period before the joint survey was established are obtained by interpolating the annual GRP based on the quarterly business survey of Bank Indonesia (Survei Kegiatan Dunia Usaha). Its consistency has also been verified based on the 1991 and 1996 manufacturing census conducted by the BPS.

${ }^{23}$ For reasons of data continuity and cross-region comparability, Hill et al. (2008), McCulloch and Sjahrir (2009), among others, have also used 26 provinces in their provincial analyses.
} 
measure of output elasticity). ${ }^{24}$ In general, we find that an unanticipated increase in the monetary policy rate reduces real output growth. ${ }^{25}$ Output tends to fall following a policy shock, after reaching a maximum (lowest) point, and then it shows a tendency to return to an equilibrium over a 20 quarters period after the shock. ${ }^{26}$ In other words, the output trajectory generally shows a hump-shaped response pattern. Given that all the regions face a uniform policy shock, impulse responses generally indicate common evidence of cross-regions differential effects that is described by both the size and the timing of the output effects, both between- and within-zones.

The maximum output responses to the policy shocks in the Java zone (Figures $2 \mathrm{i}-2 \mathrm{n}$ ) tend to be relatively large (1.87 per cent), while the national (weighted) average is ( 2.81 per cent). Between zones, Java is also reported as the zone most affected by the policy changes, while Sumatra (Figures 2a-2h) comes second with 0.53 per cent, which is followed by Kalimantan (Figures 2o-2r) by about 0.23 percent. Sulawesi (Figures 2s-2v) and Eastern Indonesia (Figures $2 \mathrm{w}-2 \mathrm{z}$ ) come afterwards with their output effects fall by about 0.10 per cent and 0.08 per cent, respectively. This clearly reveals that there are substantial variations in the policy impacts across Indonesian regions.

\footnotetext{
${ }^{24}$ The impulse responses measure the effect of a 1 standard deviation (SD) shock in the BI rate on regional output. Knowing an SD of the interest rate over the sample period, and incorporating the size of output effects taken from the impulse response, we can show the effects in percentage form (as shown in figures $2 \mathrm{a}-2 \mathrm{z}$ ).

${ }^{25} \mathrm{By}$ and large, the output effects across regions are statistically significant after the first eight quarters following a policy shock and rarely significant thereafter. This inference is based on the 95 per cent confidence intervals that are computed using the Efron-Hall Bootstrap method (500 replications) of the estimated VAR.

${ }^{26}$ The maximum response is the percentage difference between initial output and the lowest point of the impulse response function in the negative zone of the IRF graph.
} 
a) Aceh

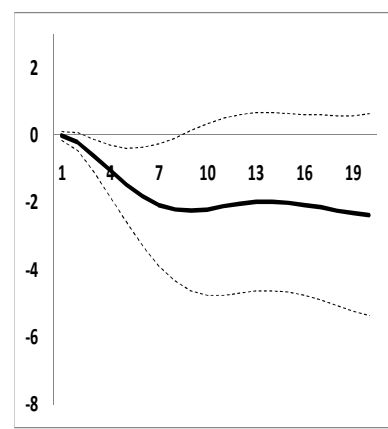

e) Jambi

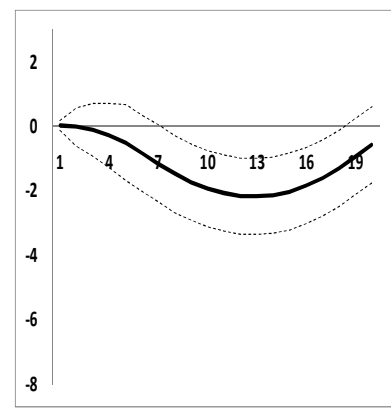

i) DKI Jakarta

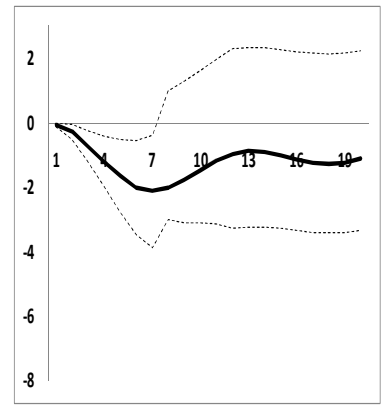

m) East Java

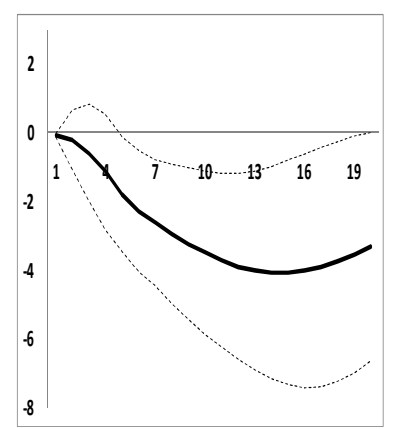

b) North Sumatra

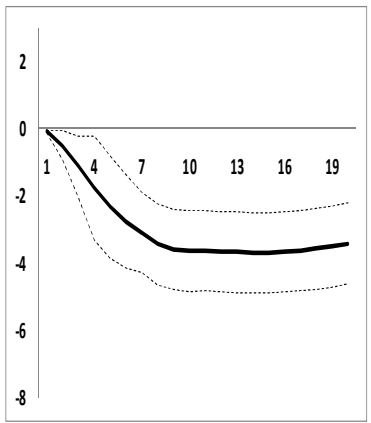

f) South Sumatra

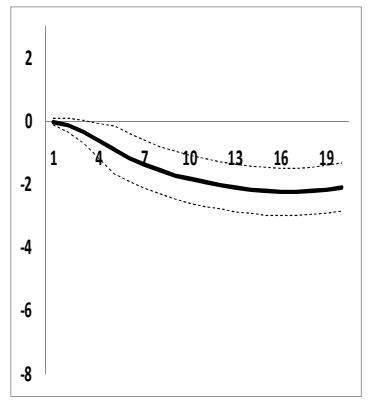

j) West Java

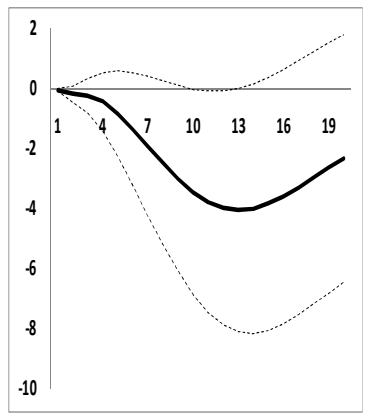

n) Bali

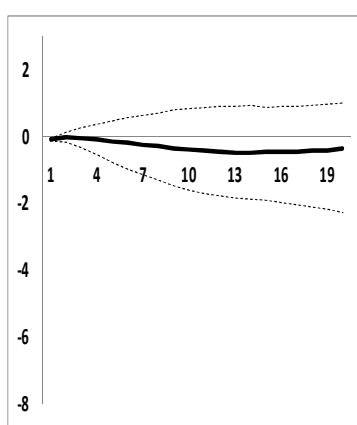

c) West Sumatra

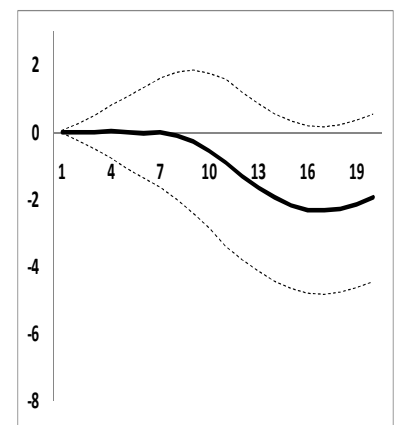

g) Bengkulu

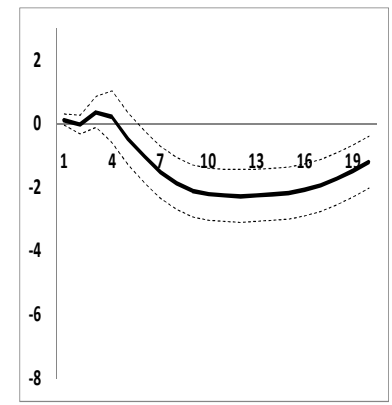

k) Central Java

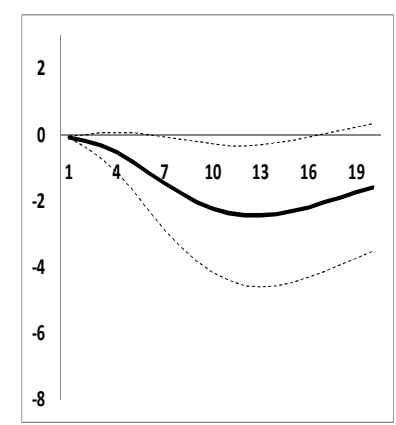

o) West Kalimantan

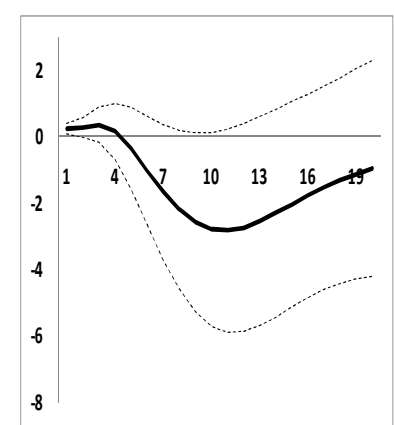

d) Riau

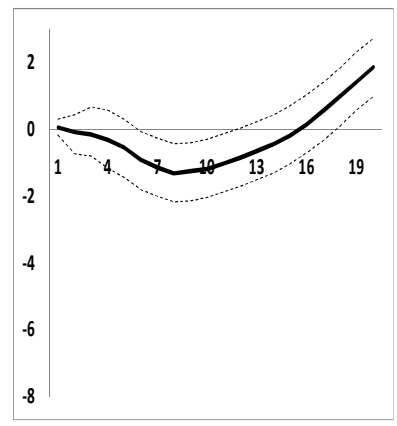

h) Lampung

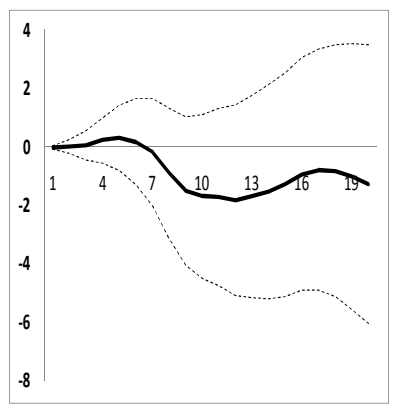

1) DI Yogyakarta

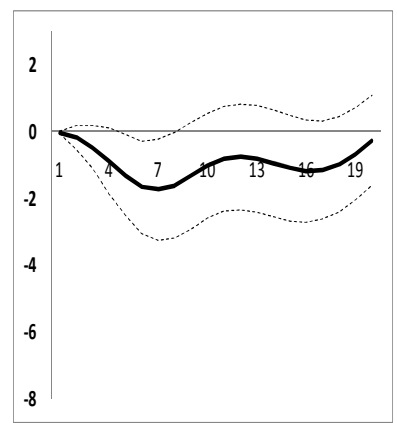

p) Central Kalimantan

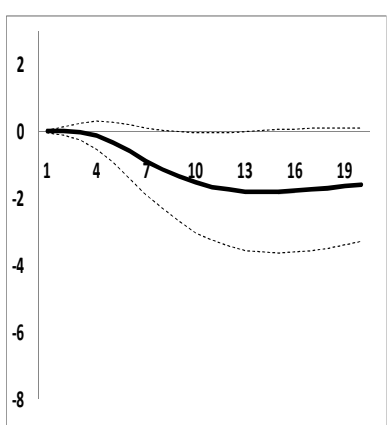

Figure 2. Impulse response of local output to a 1\%-point interest rate increase (x-axis: time in quarters; $y$-axis: output effect in percentages) 
q) South Kalimantan

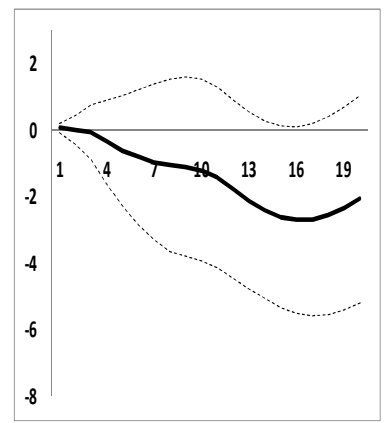

u) South Sulawesi

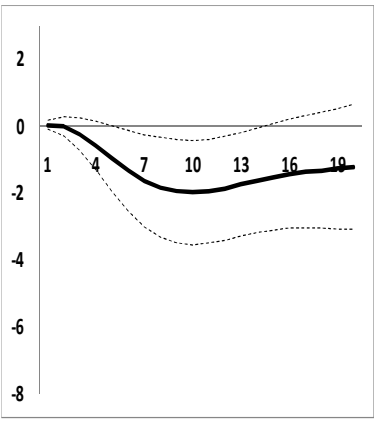

y) Maluku

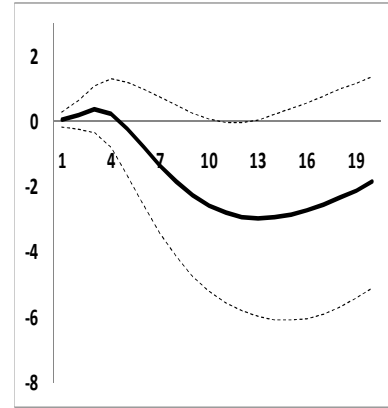

r) East Kalimantan

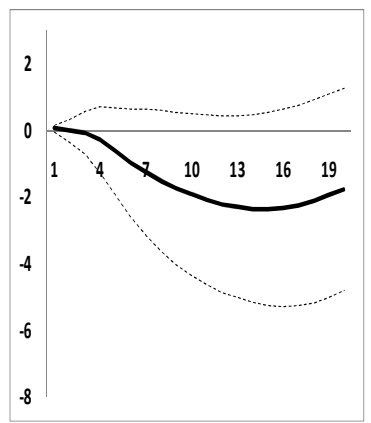

v) Southeast Sulawesi

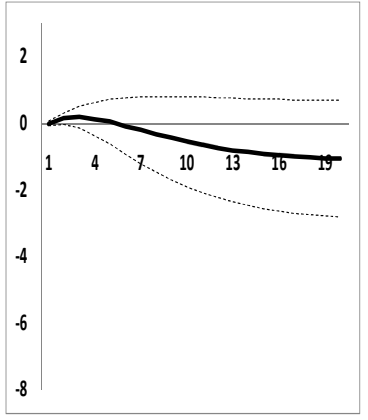

z) Papua

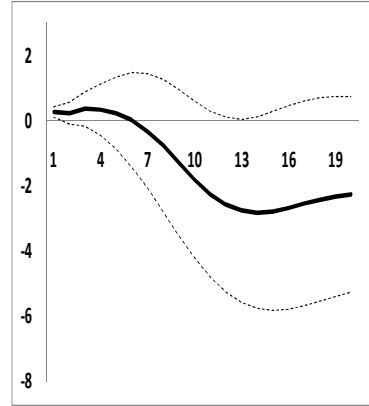

s)North Sulawesi

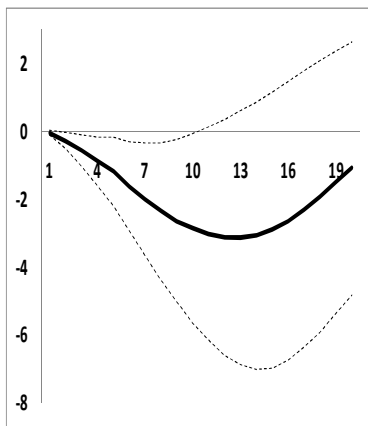

w) West Nusa Tenggara

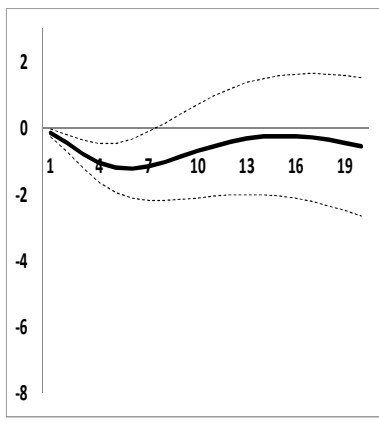

t) Central Sulawesi

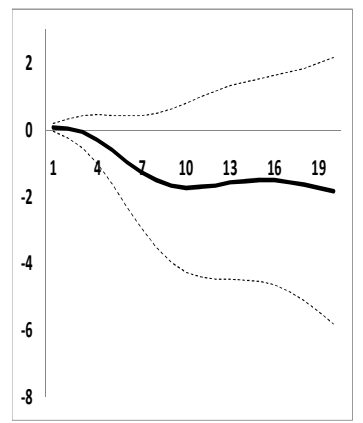

x) East Nusa Tenggara

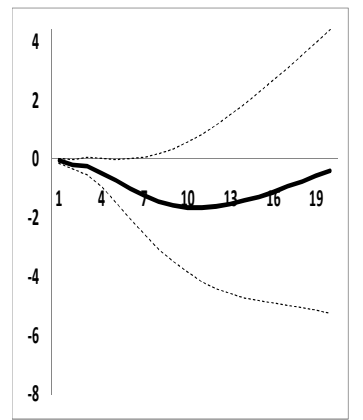

Figure 2 - continued. Impulse response of local output to a 1\%-point interest rate increase (x-axis: time in quarters; $y$-axis: output effect in percentages).

In order to verify regional heterogeneities in the policy responses, we can use the coefficient of variation $(\mathrm{CV})$, which essentially measures the degree of dispersion in interest rate sensitivity across regions within the island (zone). Java-Bali tends to show the largest CV by about 1.34, and thus, it may indicate the zone which has the highest gap between the most-and the least-affected provinces by the shocks. Meanwhile, Eastern Indonesia indicates the lowest degree of variation (CV) by about 0.09 , and hence indicates less within-zone variation compared with other zones. 
Turning to provincial analysis, the output effects also tend to exhibit quite substantial differences at the maximum level (see Figure 2). Among the provinces, West Java with a 17 per cent share of GDP share experiences the highest output loss by about 4.07 per cent (statistically significant) relative to the national average (2.28 per cent) at maximum impact. This province is notable for being the home base for the national manufacturing industry (for further details, see Ridhwan, 2011). Other manufacturing regions such as East Java, North Sumatera, and East Kalimantan also show up as provinces with high sensitivity to monetary policy actions, where their GRPs falls by 4.05 per cent (statistically insignificant), 3.67 per cent (statistically significant), and 2.36 per cent (statistically significant), respectively (see Figure 3).

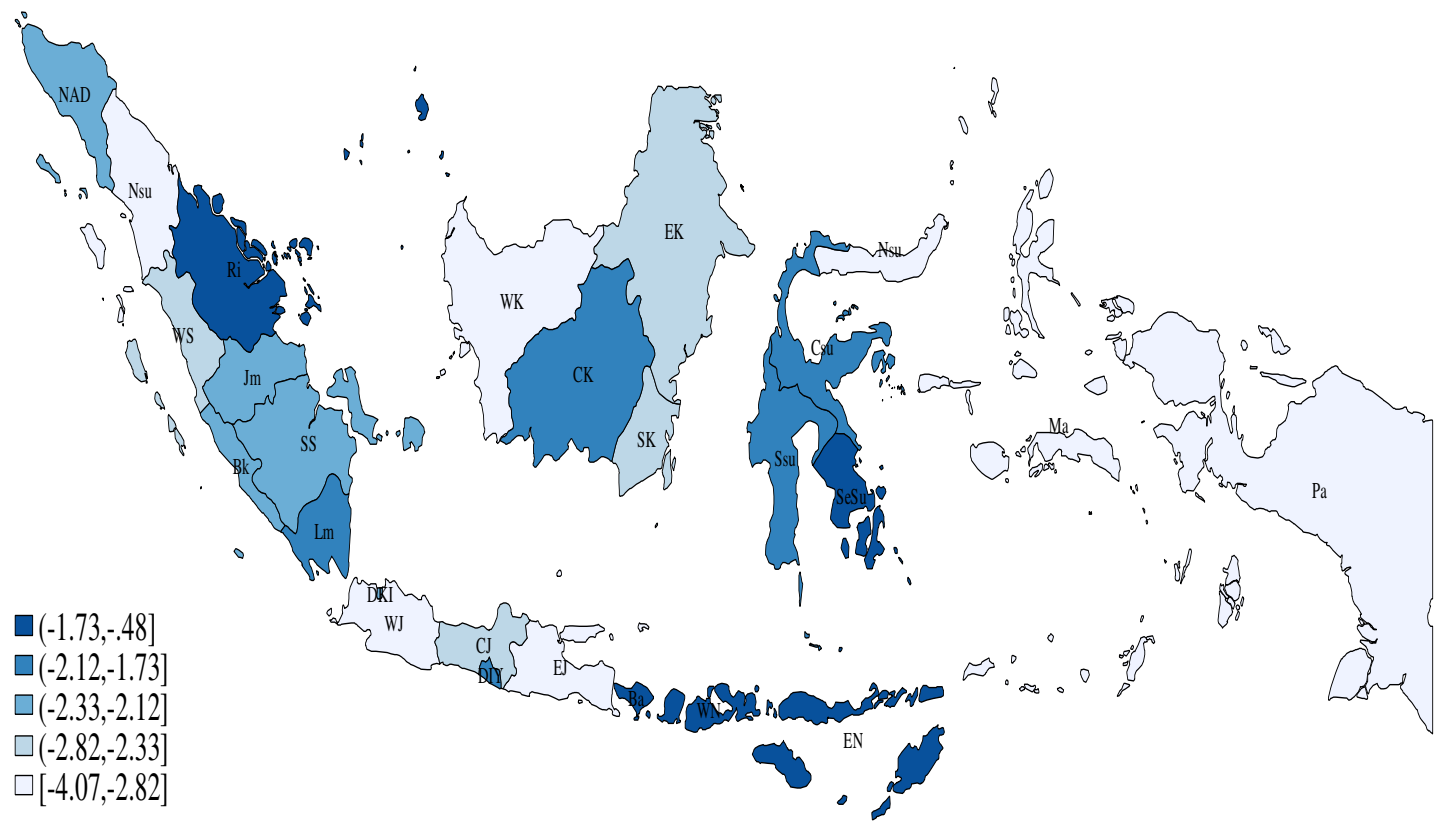

Figure 3. Spatial variation in maximum response

In contrast, Bali and Riau are regions with the lowest sensitivity to the interest rate shocks. Their output falls by 0.48 per cent and 1.33 per cent, respectively. Bali's economy is more dependent on external revenues especially from tourism, and hence is more likely to be able to avoid negative impacts from the policy shock. Likewise, Riau tends to be shielded from the shock, as its economy is also more dependent on external revenues from its extractive industries, whereby the region is known as a prominent oil-gas exporter. In addition, given its 
adjacency to Singapore, it may have wider access to international markets. Having listed all regions' impacts, it can be inferred that there is a substantial dispersion in the policy effects. The coefficient of variation (CV) is 0.38 following the policy shocks.

The impulse responses of monetary policy shocks over 20 quarters also indicate regional heterogeneities (Figure 4 ) ${ }^{35}$ Riau is the province with the fastest recovery speed (moving back to a equilibrium position) after its output had fallen in response to the interest rate shocks (see also Figure 2b). Meanwhile, North Sumatra and East Java are regions that experience the largest impacts after 20 quarters of the policy shocks. Output in these regions falls by 3.41 per cent and 3.30 per cent, respectively.

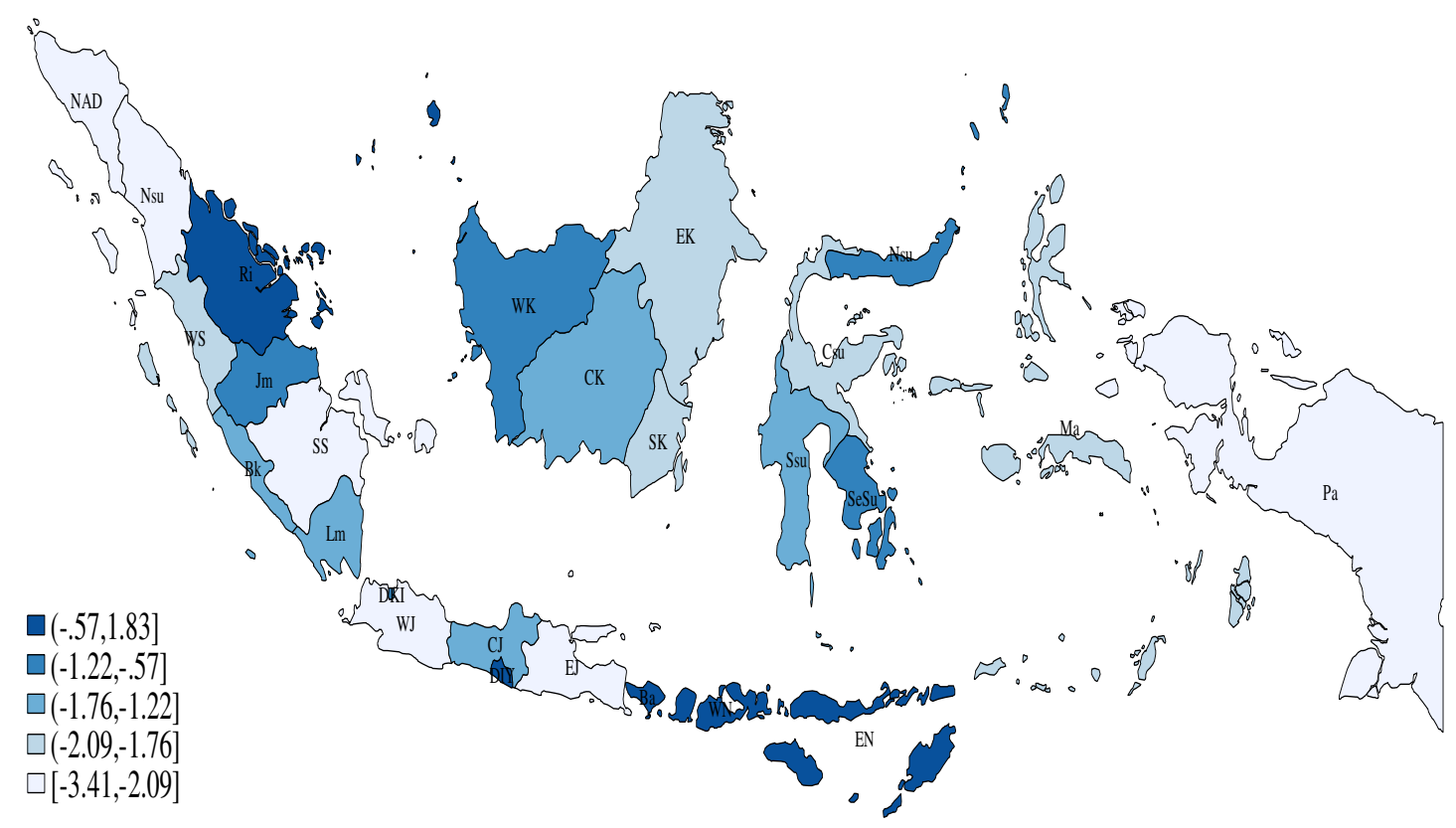

Figure 4. Spatial variation in the twentieth-quarter response

Furthermore, the adjustment speed to the shocks across regions that is shown the by timeelapsed at maximum impact also exhibits noticeable heterogeneities (Figure 5). Southeast Sulawesi takes almost 20 quarters to achieve the maximum effect relative to the national average of 12 quarters. West Sumatra and South Kalimantan, also experience considerably longer effects of about 16-17 quarters. Meanwhile, several relatively small-sized regions take a longer time to be negatively affected by the policy shocks, i.e., Lampung (7 quarters), West Sumatra (4 quarters), Maluku (4 quarters), and Papua (6 quarters). 


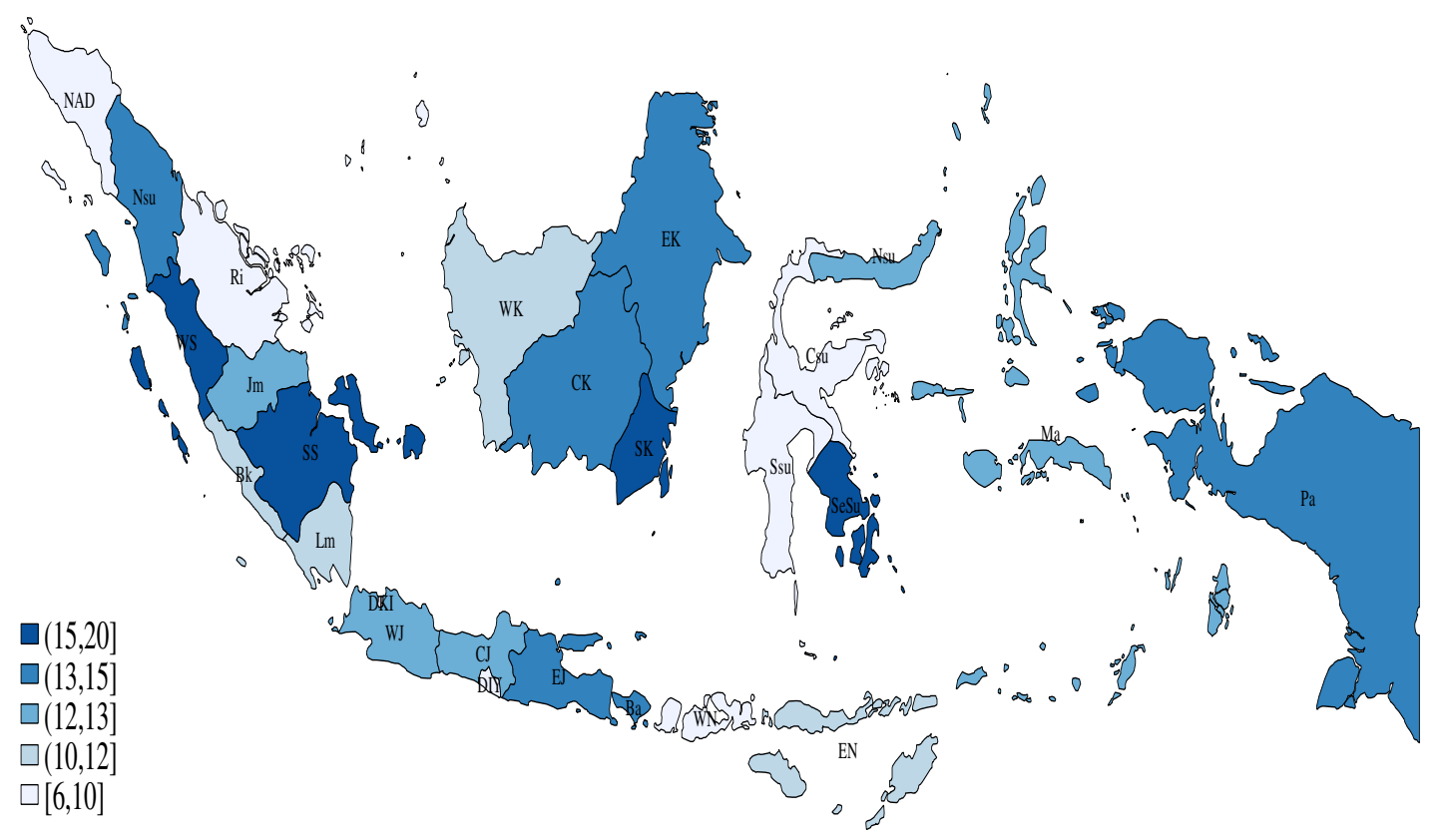

Figure 5. Spatial variation of time-elapsed at maximum impact (in quarters)

\subsection{Sources of heterogeneous responses and regional transmission channels}

The general findings of our VAR analysis so far have shown compelling evidence of differences in regional responses following monetary policy actions. Yet it is also of interest to further examine what factors give rise to the regional asymmetries. Therefore, we will now examine the key factors that are able to explain such differential regional effects. In addition, this analysis may also provide information regarding regional monetary transmission channels operating in Indonesia, viz. the interest rate, credit rate and exchange rate (see Section 2).

Following Ridhwan et al. (2010), we identify several sources of regional heterogeneity in the response to the monetary policy shock. First, there is the share of manufacturing to GRP (gross regional domestic products) that is used as a measure to capture regional (provincial) differences in this capital-intensive sector, or industrial mix. As mentioned earlier, this variable has information-content for the interest-rate channel of monetary policy. To account for regional differences in the mix of firm size (broad credit channel), we use the percentage share of a region's small firms (firms with fewer than 19 employees). ${ }^{27}$ We also employ the percentage of a region's total loans made by the province's rural banks (Bank Perkreditan Rakyat, or BPR) to highlight the importance of a region's structure in bank size (narrow credit

${ }^{27}$ Based on BPS data (see, Tambunan, 2009). 
channel). ${ }^{28}$ To capture the role of inflation heterogeneities in explaining variations in the output effects of monetary policy, we employ the regional inflation rate based on the Consumer Price Index (CPI) with the 2002 base year. The share of exports to GRP (in per cent) is used to measure differences in cross-region degree of openness. This variable may also capture an exchange rate channel. The size of GRP is used to represent regional differences in economic size.

The dependent variables are derived from the estimated cumulative impulse responses based on the previous VAR model. We consider the maximum output effect, the fourthquarter effect, the twentieth-quarter effect, and time-elapsed at the maximum effect, respectively. Since the output effects have a negative sign except for the latter indicator, the interpretation of the estimation results will be easier when conducted in absolute terms. The results are presented in Table 2 .

The results reveal that the share of the manufacturing sector in GRP has a positive and statistically significant effect (in absolute terms) primarily in the maximum and the twentiethquarter response regressions. This finding tends to support the existing literatures that regional differences in industrial composition play an important role in explaining the differential effects of monetary policy in Indonesia. It also suggests the existence of an interest rate channel of monetary policy. The share of small firms has a positive and statistically significant effect. As predicted by theory, regions with a higher share of small firms experience larger output losses following a monetary tightening, pointing at the importance of a broad credit channel. The share of small bank loans is found to be positive and statistically significant, although only in the twentieth quarter effect model (Column 3). This result confirms to relevance of a narrow credit channel. ${ }^{29}$ For the inflation rate, we find a significant effect only in the twentieth quarter effect with the expected sign. We find no statistical evidence for an effect of regional economic size. Likewise, regional variations in the degree of openness as proxied by the percentage share of total exports and imports to GRP do not contribute to the explanation of output responses. ${ }^{30}$ In addition, we have introduced a core-periphery dummy

\footnotetext{
${ }^{28}$ This could be an alternative measure of the financial variable as well.

${ }^{29}$ Using a similar estimation approach, Carlino and DeFina (1999) are unable to find statistically significant effects for the firm size (percentage of small firms) and bank size (percentage of small banks' loans) measure.

${ }^{30}$ Ridhwan et al. (2010) also found no statistically significant role of regional differences in trade patterns in explaining the regional effects.
} 
(equal to one for Java and zero for Off-Java regions) in a separate regression, and the result turns out to be statistically insignificant. ${ }^{31}$

Table 2. Variation in the output response following an interest rate shock

\begin{tabular}{|c|c|c|c|c|}
\hline \multirow[b]{2}{*}{$\begin{array}{l}\text { Explanatory } \\
\text { Variables }\end{array}$} & \multicolumn{4}{|c|}{ Dependent Variables } \\
\hline & $\begin{array}{l}\text { Maximum effect } \\
\text { (\%-point) }\end{array}$ & $\begin{array}{l}\text { The fourth- } \\
\text { quarter effect } \\
\text { (\%-point) }\end{array}$ & $\begin{array}{l}\text { The twentieth- } \\
\text { quarter effect } \\
\text { (\%-point) }\end{array}$ & $\begin{array}{l}\text { Time elapsed at } \\
\text { maximum effect } \\
\text { (in quarters) }\end{array}$ \\
\hline Manufacturing sector & $-0.039^{* * *}$ & -0.019 & $-0.027^{* *}$ & -0.133 \\
\hline (\% of GRP) & $(0.01)$ & $(0.12)$ & $(0.01)$ & $(0.10)$ \\
\hline \multirow[t]{2}{*}{ Small firms' share } & $-0.042^{* *}$ & 0.004 & $-0.031^{\text {** }}$ & -0.071 \\
\hline & $(0.02)$ & $(0.01)$ & $(0.01)$ & $(0.09)$ \\
\hline \multirow[t]{2}{*}{ Small bank loans' share } & -0.013 & -0.002 & $-0.029^{* *}$ & 0.055 \\
\hline & $(0.01)$ & $(0.01)$ & $(0.01)$ & $(0.77)$ \\
\hline \multirow[t]{2}{*}{ Inflation rate } & 0.125 & 0.116 & $0.131^{* *}$ & 0.327 \\
\hline & $(0.14)$ & $(0.07)$ & $(0.06)$ & $(0.67)$ \\
\hline \multirow[t]{2}{*}{ Size of GRP } & 0.035 & 0.104 & -0.095 & -1.834 \\
\hline & $(0.22)$ & $(0.07)$ & $(0.07)$ & $(1.19)$ \\
\hline \multirow[t]{2}{*}{ Exports (\% of GRP) } & -0.001 & 0.004 & 0.002 & -0.024 \\
\hline & $(0.00)$ & $(0.00)$ & $(0.00)$ & $(0.03)$ \\
\hline \multirow[t]{2}{*}{ Constant } & 1.441 & $6.084^{* *}$ & 1.473 & $48.329^{* *}$ \\
\hline & $(4.42)$ & $(2.91)$ & $(4.93)$ & (21.48) \\
\hline$N$ & 26 & 26 & 26 & 26 \\
\hline $\operatorname{Adj} R^{2}$ & 0.533 & 0.408 & 0.546 & 0.168 \\
\hline
\end{tabular}

Notes: Robust standard errors in parentheses. Asterisks indicate statistical significance: ${ }^{*}$ significant at the $10 \%$ level, ${ }^{* *}$ significant at the $5 \%$ level, and ${ }^{* * *}$ significant at the $1 \%$ level.

Summarizing, our findings are in line with previous findings in Ridhwan et al. (2010) who conducted a meta-analysis on the sources of heterogeneity in regional responses to monetary shocks. Cross-regional differential responses to monetary policy actions can be primarily explained by the region's industrial composition (economic structure). Other significant sources of heterogeneity are the share of small firms and small banks in the regions.

In addition, having compared this finding with the results from the former study that is applied in developed countries, the regional output fall in Indonesia (on average) is considerably higher (2.28 per cent) than in developed countries ( 0.77 per cent) at the maximum effect, while, the time-elapsed to reach the maximum effect in Indonesia is, on average, longer (12.0 quarters) than in the latter countries (8.3 quarters).

\footnotetext{
${ }^{31}$ For brevity, we do not show the results here, and the exclusion of the dummies (from the basic model) did not affect the results as reported in the table.
} 


\section{Conclusions}

We have analyzed whether monetary policy had symmetric effects across Indonesia's 26 provincial economies during the 1990:1-2007:4 period by means of vector autoregression (VAR) models. Impulse response functions from the estimated models reveal considerable regional differences in policy responses. West Java, the largest manufacturing-based province, tends to be the most affected by an unanticipated one percentage point increase in the monetary policy rate (4.07 per cent) at the maximum effect, while Bali's economy appears to be the least-affected province ( 0.48 per cent). Sulawesi and Eastern Indonesia, which are both highly dependent on the agricultural sector, are also less affected by the policy shocks, while Java island, which is predominantly manufacturing-based, is more sensitive to monetary policy actions. Consistent with theory, a contractionary monetary policy will be followed by the temporary fall of output, and, after reaching the maximum (the lowest) point, the output tends to head back to its equilibrium position (a hump-shaped curve). It also appears that the impacts of monetary policy shocks (in terms of output loss) tend to be much larger in developing countries (Indonesia's case) than in developed countries.

This study also supports previous findings from the mainstream literature, concerning the importance of cross-regional industrial composition (as proxied by the share of manufacturing) in explaining the differences in the response to monetary policy. This suggests the relevance of the interest rate channel of monetary policy. We also found regional differences in the role played by firm size and bank size in explaining the regional effects, and, hence, to some extent they suggest the relevance of the credit channel. Consequently, this study supports a previous study by Bank Indonesia (Warjiyo and Agung, 2002), which was based on aggregate (national) level data, where the relevance of the interest rate and the credit channel of monetary policy were established. 


\section{References}

Arnold, I.J.M. and Vrugt, E.B. (2004). Firm size, industry mix and the regional transmission of monetary policy in Germany. German Economic Review, 5(1): 35-59.

Athanasoulis, S.G. and Van Wincoop, E. (2001). Risk sharing within the United States: What do financial markets and fiscal federalism accomplish? Review of Economics and Statistics, 83(4): 688-698.

Baldwin, R.E. and Wyplosz, C. (2004). The Economics of European Integration. New York: McGraw-Hill.

Barth III, M.J. and. Ramey, V.A. (2001). The cost channel of monetary transmission. NBER Macroeconomics Annual, 16: 199-240.

Beckworth, D. (2010). One nation under the FED? The asymmetric effects of US monetary policy and its implications for the United States as an optimal currency area. Journal of Macroeconomics, 32(3): 732-746.

Ber, H., Blass, A. and Yosha, O. (2001). Monetary transmission in an open economy: The differential impact on exporting and non-exporting firms. Bank of Israel Discussion Paper, No. 1-2001.

Bernanke, B.S. and Blinder, A.S. (1992). The federal funds rate and the channels of monetary transmission. American Economic Review, 82(4): 901-921.

Bernanke, B.S. (1986). Alternative explanations of money-income correlation. CarnegieRochester Conference Series on Public Policy, 25: 49-100.

Bernanke, B.S. and Gertler, M. (1995). Inside the black box, the credit channel of monetary policy transmission. Journal of Economic Perspectives, 9: 27-48.

Blanchard, O.J. and Quah, D. (1989). The dynamic effects of aggregate demand and supply disturbances. American Economic Review, 79(4): 655-673.

Carlino, G. and DeFina, R.H. (1998). The differential regional effects of monetary policy. Review of Economics and Statistics, 80: 572-587.

Carlino, G. and DeFina, R.H. (1999). The differential regional effects of monetary policy: evidence from the U.S. States. Journal of Regional Science, 39: 339-358.

Clements, B., Kontolemis, Z., Levy, J. and Joaquim, V. (2001) Monetary policy under EMU: Differences in the transmission mechanism. IMF Working Paper, no. 01/102.

Christiano, L.J., Eichenbaum, M. and Evans, C.L. (1998). Monetary policy shocks: What have we learned and to what end? NBER Working Paper, no. W6400.

Cochrane, J.H. (1998). What do the VARs mean? Measuring the output effects of monetary policy. Journal of Monetary Economics, 41: 277-300.

Darby, J. and Phillips, H. (2007). Exploring the implications of UK monetary policy for sectors of the UK and Scottish economies. CPPR Discussion Paper, no. 16.

Dedola, L. and Lippi, F. (2005). The monetary transmission mechanism: Evidence from the industries of five OECD countries. European Economic Review, 49: 1543-1569.

De Grauwe, P. (1994). Economics of Monetary Union. Oxford: Oxford University Press.

Dow, S.C. and Montagnoli, A. (2007). The regional transmission of UK monetary policy. Regional Studies, 41: 797-808.

Ehrmann, M. (1998). Will EMU generate asymmetry? Comparing monetary policy transmission across European countries. EUI Working Paper, no. 28.

Enders, W. (2004). Applied Econometrics Time Series. Hoboken, NJ: John Wiley and Sons.

Faust, J. (1998). The robustness of identified VAR conclusions about money. CarnegieRochester Conference Series on Public Policy, 49: 207-244. 
Favero, C.A. (2001). Applied Macroeconometrics. Oxford: Oxford University Press.

Fishkind, H.H. (1977). The regional impact of monetary policy: An economic simulation study of Indiana (1958-1973). Journal of Regional Science, 17: 77-88.

Frantantoni, M. and Schuh, S. (2003). Monetary policy, housing, and heterogeneous regional markets. Journal of Money, Credit and Banking, 35: 557-589.

Ganley, J. and Salmon, C. (1997). The industrial impact of monetary policy shocks: Some stylised facts. Bank of England Working Paper, no. 68.

Garrison, C.B. and Chang, H.S. (1979). The effect of monetary and fiscal policies on regional business cycles. International Regional Science Review, 4: 167-180.

Gertler, M. and Gilchrist, S. (1993). The role of credit market imperfections in the monetary transmission mechanism: Arguments and evidence. Scandinavian Journal of Economics, 95(1): 43-64.

Hamilton, J.D. (1994). Time Series Analysis. New Jersey: Princeton University Press.

Hardiyanto, A.V. (2007). Time Series Studies on Indonesian Rupiah/USD Rate 1995-2005. Tinbergen Research Series, no. 390.

Hanson, M.S., Hurst, E. and Park, K.Y. (2006). Does monetary policy help least those who need it most. Wesleyan Economics Working Papers, no. 2006-006.

Hayo, B. and Uhlenbrock, B. (2000). Industry effects of monetary policy in Germany. In: Von Hagen, J. and Waller, C. (eds), Regional Aspects of Monetary Policy in Europe. Boston: Kluwer.

Hill, H. (2000). Indonesia: The strange and sudden death of a tiger economy. Oxford Development Studies, 28(2): 117-139.

Hill, H., Resosudarmo, B.P. and Vidyattama, Y. (2008). Indonesia's changing economic geography. Bulletin of Indonesian Economic Studies, 44(3): 407-435.

Johansen, S., Mosconi, R. and Nielsen, B. (2000). Cointegration analysis in the presence of structural breaks in the deterministic trend. Econometrics Journal, 3(2): 216-249.

Juselius, K. (2005). The Cointegrated VAR Model: Methodology and Applications. Oxford University Press, USA.

Kashyap, A.K. and Stein, J.C (2000). What do a million observations on banks say about the transmission of monetary policy? American Economic Review, 90(3): 407-428.

King, R.G ., Plosser, C.I., Stock, J.H., and Watson, M.W. (1991). Stochastic trends and economic fluctuations. American Economic Review 81(4): 819-840.

Kouparitsas, M.A. (1999). Is the EMU a viable common currency area? A VAR analysis of regional business cycles. Economic Perspectives - Federal Reserve Bank of Chicago, Q IV: $2-20$.

Krugman, P. (1991). Increasing returns and economic geography. Journal of Political Economy, 99: 483-499.

Lanne, M., Lütkepohl, H. and Saikkonen, P. (2002). Comparison of unit root tests for time series with level shifts. Journal of Time Series Analysis, 23(6): 667-685.

Leeper, E.M., Sims, C.A., and Zha, T. (1996). What does monetary policy do? Brookings Papers on Economic Activity, 2: 1-63.

Lütkepohl, H. (2007). New Introduction to Multiple Time Series Analysis, $2^{\text {nd }}$ edn. Berlin, Springer.

McCulloch, N. and Sjahrir, B.S. (2008). Endowments, location or luck? World Bank, Policy Research Working Paper, no. 4769.

Miller, R.J. (1978). The Regional Impact of Monetary Policy in the United States. Lexington, MA: Lexington Books. 
Mishkin, F.S. (1996). The channels of monetary transmission: lessons for monetary policy. National Bureau of Economic Research Working Paper, no. 5464.

Oliner, S.D., and Rudebusch, G.D. (1996). Is there a broad credit channel for monetary policy? Federal Reserve Bank of San Francisco-Economic Review: 3-13.

Owyang, M.T. and Wall, H.J. (2009). Regional VARs and the channel of monetary policy. Applied Economics Letters, 16: 1191-1194.

Peersman, G. and Smets, F. (2005). The industry effects of monetary policy in the euro area. Economic Journal, 115: 319-342.

Ramaswamy, R. and Sløk, T. (1998). The real effects of monetary molicy in the European Union: What are the differences? Staff Papers - International Monetary Fund, 45(2): 374-396.

Ridhwan, M.M., De Groot, H.L.F., Nijkamp, P. and Rietveld, P. (2010). The impact of monetary policy on economic activity: Evidence from a Meta-Analysis. Tinbergen Institute Discussion Paper, no. 043/3.

Ridhwan, M.M. (2011). Regional Dimensions of Monetary Policy in Indonesia. Tinbergen Institute Research Series, no. 499. Amsterdam, Rozenberg Publishers.

Rodriguez-Fuentes, C.J. (2005). Regional Monetary Policy. London: Routledge.

Saikkonen, P. and Lütkepohl, H. (2000). Testing for the cointegrating rank of a VAR process with structural shifts. Journal of Business \& Economic Statistics, 18(4): 451-464.

Schunk, D. (2005). The differential impacts of monetary policy: Are the differences diminishing? Papers in Regional Science, 84(1): 127-136.

Shapiro, M.D. and Watson, M.W. (1988). Sources of business cycle fluctuations. NBER Macroeconomic Annual, 3: 111-148.

Sims, C.A. (1980). Macroeconomics and reality. Econometrica, 48: 1-48.

Sims, C.A. (1986). Are forecasting models usable for policy analysis. Federal Reserve Bank of Minneapolis Quarterly Review (Winter edition): 3-16.

Tambunan, T.H. (2009). SMEs in Asian Developing Countries. New York: Palgrave Macmillan.

Taylor, J. (1995). The monetary transmission mechanism: An empirical framework. Journal of Economic Perspectives, 9: 11-26.

Von Hagen, J. (1999). A fiscal insurance for the EMU? In: Beetsma, R.M.W.J. and Oudshoorn, C. (eds). Tools for Regional Stabilisation. Dutch Ministry of Economic Policy Discussion Paper, no. 9903.

Warjiyo, P. and Agung, J. (2002). Transmission Mechanisms of Monetary Policy in Indonesia. Jakarta: Bank Indonesia. 


\section{Appendix A. Unit Root Test}

This Appendix presents the result of unit root tests that are applied to all variables used in our VAR model, as explained in Section 3. The tests are an ADF test (Augmented Dickey-Fuller), a PP test (Phillips-Perron), and an LLS test (Lanne, Lütkepohl and Saikkonen), respectively.

As explained by Lütkepohl and Krätzig (2004), if there is a shift in the level of the DGP (data-generating process), it should be taken into account in testing for a unit root because the ADF test may be distorted if the shift is simply ignored. Thereafter, they suggest employing the LLS test (Lanne et al., 2002), in which the unit root test also takes into account structural breaks. Initially, we assume the break date is unknown, but, later on the basis of the findings, we test the break date in an endogenous way (see Section 3.2).

\begin{tabular}{lccccccc}
\hline \multicolumn{1}{c}{ Variable } & $y n$ & $p n$ & $r$ & $e$ & $y i$ & $p c$ & $f r$ \\
\hline ADF test statistic & -2.60 & -0.50 & $-2.84^{*}$ & -2.18 & -2.48 & $-4.21^{*}$ & $-3.13^{* *}$ \\
PP test statistic & -0.89 & -0.46 & $-2.80^{*}$ & -1.90 & -1.54 & $-4.06^{*}$ & $2.93^{* *}$ \\
LLS test statistic & -1.55 & 0.93 & $-2.39^{*}$ & $-2.98^{*}$ & -1.62 & $-4.30^{*}$ & $-3.50^{* *}$ \\
\hline
\end{tabular}

Notes:

1) $y n$ is the log of real GDP ; $p n$ is the log of CPI; $r$ is the 30-day interbank money market; $e$ is the exchange rate of the USD against the rupiah (Rp); $y i$ is the log of real GRP; $p c$ is the log of world commodity prices; and $f r$ is the 3-month SIBOR.

2) Asterisks indicate statistical significance: * significant at the $10 \%$ level, ${ }^{* *}$ significant at the $5 \%$ level, and ${ }^{* * *}$ significant at the $1 \%$ level.

3) The null hypothesis is the presence of a unit root in the series.

4) Including intercept, seasonal dummies, and linear trend.

5) Lag Length: 2 (based on Schwarz Information Criteria/SIC and Hannan Quinn/HQ)

6) Asymptotic critical values for the ADF test are based on Davidson and MacKinnon (1993); the PP test is based on MacKinnon (1996); and the LLS test is based on Lanne, Lütkepohl and Saikkonen, 2002.

7) Since there are 26 regions, for the sake of brevity, here we only show one region as a representative of the yi variable. 